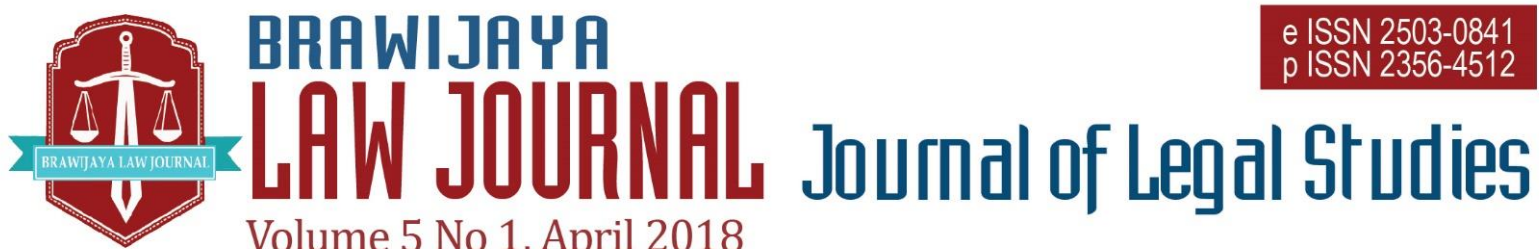

Volume 5 No 1, April 2018

Nationally Accredited No. 32a/E/KPT/2017 Dated 26th April 2017

This work is licensed under a Creative Commons Attribution-NonCommercial 4.0 International License

\title{
Fundamental Rights in Times of Emergency: Ataur Rahman vs Muhibur Rahman' ${ }^{1}$ Revisited
}

\author{
Md Mustakimur Rahman ${ }^{1}$ \\ ${ }^{1}$ Department of Law, Notre Dame University Bangladesh. \\ E-mail : mrahman.ntu@outlook.com
}

Submitted : 2017-10-12 | Accepted : 2018-04-11

\begin{abstract}
This research analyses the Bangladesh' Court Decision on the case of Ataur Rahman vs. Mahibur Rahman with regrad to fundamental rights in times of emergency. It is argued that the decision of the court in Ataur Rahman vs. Muhibur Rahman is erroneous decision. This is because while Article 141C of Bangladesh Constitution gives the Presidnet the power to suspend certain fundamental rights, yet Articles 27 to 35 and 41 of the Constitution cannot be suspended. In Bangladesh's legal system, fundamental human rights are commonly viewed as a set of legal protections. Part III of the Constitution of Bangladesh has confirmed these rights for the citizens of Bangladesh. Some fundamental rights are even universally recognized rights which are contained in the United Nations Universal Declaration of Human Rights (UDHR), the UN International Covenant on Civil and Political Rights (ICCPR), or the UN International Covenant on Economic, Social and Cultural Rights (ICESCR). Article 4 of the ICCPR deals with the state of emergency and Article 4(2) provides a list of non-derogable rights. Such as the right to life, the prohibition of torture, slavery etc. These rights are completely non-derogable in nature and cannot be derogated at all including during a state of emergency. Furthermore the Apex court of Bangladesh tried to justify that the President can derogate any fundamental right during an emergency. Such a proposition is contradicting core parts of our Constitution as well as several international instruments.

This research uses normative legal research with statute approach and case approach, especialy analysing Ataur Rahman vs. Muhibur Rahman case.
\end{abstract}

Keywords: Fundamental Rights,Emergency, Bangladesh, Constuitutional Law, International Law

\section{INTRODUCTION}

The provision of the state of emergency in our constitution ${ }^{2}$ deals with the situation when there are some imbalances in the society. Under certain international human rights treaties, state parties are allowed to derogate from a number of human rights to adjust their obligations for a limited period of

\footnotetext{
14 BLC (AD) 63 (2009)

${ }^{2}$ Article 141A(1) of the Constitution of the People's Republic of Bangladesh 1972 states that "If the President is satisfied that a grave emergency exists in which the security or economic life of Bangladesh, or any part thereof, is threatened by war or external aggression or internal disturbance, he may issue a Proclamation of Emergency."
} 
time in some exceptional circumstances; i.e. in the time of state emergency threatening the life of the nation. ${ }^{3}$ A government can take some exceptional measures; however, their validity is subject to adherence to a number of requirements set by the treaty law. ${ }^{4}$ Such as qualifications of severity, temporaries, proclamation and notification, legality, proportionality, consistency with other obligations under international law, nondiscrimination, and to finish, nonderogability of certain rights recognized as such in the relevant treaties. The aim of any derogation is to strike a balance between individual protection and the protection of national interest at the time of grave necessity. ${ }^{5}$ The concept of "necessity" came to the front in the case of The State[Pakistan] vs. Dosso and Another [1958] PLD SC (PAK.) 533 in which the Chief Justice Muhammad Munir observed that:

"If the revolution is victorious in the sense that the persons assuming power under the change can successfully require the inhabitants of the country to conform to the new regime becomes a law creating fact.... Thus a victorious revolution or a successful coup d'etat is an internationally-recognised legal method of changing a constitution."

\footnotetext{
3 Human Rights Committee, General Comment 29(2001), Article 2 (The Human Rights Committee is the body of independent experts that monitors implementation of the International Covenant on Civil and Political Rights by its State parties); International Covenant on Civil and Political Rights 1966, Article 4(1)

${ }^{4}$ International Covenant on Civil and Political Rights 1966, Article 4(1)

5 "Doctrine of necessity" is a term used to describe the basis on which extra-legal actions by state actors, which are designed to restore order, are found to be constitutional.

6 The State[Pakistan] vs. Dosso and Another [1958] PLD SC (PAK.) 533, p 542 (1958); see also: Muhammad Nasrullah Virk, 'Doctrine of Necessity-
}

It seems like an illegal act was made legal in a way where a military man could walk in. The Supreme Court of Pakistan also held that

"Since Article 5 of the late Constitution (relating to Fundamental Rights) had disappeared from the new legal Order, the Frontier Crimes Regulation 1901 by reason of Act IV of Laws (Continuance in Force) Order 1958 was still in force. "6

Although the Lahore High Court had declared the Frontier Crimes Regulation 1901 unconstitutional, later on the Supreme Court of Pakistan held in favour of the Federal Government. The decision was based on the Hans Kelsen's theory of legal positivism. $^{7}$

According to Kelsen's theory, the key points of the judgment:

\section{a. Legalisation of $\mathbf{1 9 5 8}$ Martial Law}

The court held that the imposition of the 1958 Martial law was a kind of peaceful revolution which is not resisted by the common people. It was also accepted by the general people and they were happy with the changes; therefore, marital law was legal as long as it satisfies the common people. ${ }^{8}$

Application in Pakistan- Cases of Immense Importance-A Critical Review' 2(2), International Journal of Social Science and Education, 83 (2012)

${ }^{7}$ Legal positivism is a theory about the nature of law, commonly thought to be characterized by two major tenets: first, that there is no necessary connection between law and morality; and second, that legal validity is determined ultimately by reference to certain basic social facts, e.g., the command of the sovereign (John Austin) the Grundnorm (Hans Kelsen) or the rule of recognition (H. L. A. Hart).

${ }^{8}$ George Williams, The Case that Stopped a Coup? The Rule of Law in Fiji $\left(27^{\text {th }}\right.$ November 2003) s< http://www.victoria.ac.nz/law/centres/nzcpl/publica tions/occasional- 


\section{b. Recognition of Laws (continuance in force) order}

The court also held that the Laws (Continuance in Force) Order 1958 was the new legal Order and therefore, the validity of laws and the correctness in the judicial decisions would be determined according to it. ${ }^{9}$

During state emergency, the derogation of human rights must be proportionated and the requirement of it constitutes one of the substantive limits to the emergency powers. As Hartman observes that,

"Requiring specific scrutiny and specific justification of each measure taken in response to an emergency, rather than an abstract assessment of the overall situation." 10

This research analyses the Bangladesh' Court Decision on the case of Ataur Rahman vs. Mahibur Rahman with regrad to fundamental rights in times of emergency.

\section{LEGAL MATERIALS AND METHODS}

It is a normative legal research using primary and secondary legal materials. While the primary legal materials consist of all the international agreement related to the development of technology both directly and indirectly, secondary ones included the references, including books, journal articles as well as conference papers and other documents having correlation with the issues. The technique of analysis data used legal interpretation.

papers/publications/OP_Williams.pdf > (accessed 15 September 2016)

${ }^{9}$ ibid

10 Joan Hartman, 'Derogations from Human Rights Treaties in Public Emergencies' 22 Harvard International Law Journal, 6 (1981)

${ }^{11}$ Emilie M. Hafner-Burton, Laurence R. Helfer, and Christopher J. Fariss, 'Emergency and Escape:
Specifically, the international agreements as primary legal materials including Bangladesh Constitutionm, legislation of 1958 Martial Law, United Nations Universal Declaration of Human Rights (UDHR), the UN International Covenant on Civil and Political Rights (ICCPR), or the UN International Covenant on Economic, Social and Cultural Rights (ICESCR).

\section{RESULTS AND DISCUSSIONS}

\section{Derogation Under International}

Law:

Any state may adopt emergency measure if state faces a threat to its security. State may also suspend some civil and political liberties. This idea was discussed by the drafters of the ICCPR, European and American Conventions on Human Rights right after the Second World War. ${ }^{11}$ However, to make a balance, the drafters included a clause that restricts states to derogate certain rights during emergency. This is particularly to prevent states from arbitrarily derogating their obligations in respect of human rights during war or emergencies. ${ }^{12}$ The drafters were concern that the executive and legislature could authorise infringement individual liberties. Moreover, if the judiciary is not separated then it might be possible to approve the derogation through politicised judiciary. If this is the case, then judicial review would not be enough to protect human rights in the national level and also it would not be compatible with the international treaty like

$$
\begin{aligned}
& \text { Explaining Derogations from Human Rights } \\
& \text { Treaties,' International Organization of Duke } \\
& \text { University, } 676 \text { (2011); see: } \\
& \text { https://scholarship.law.duke.edu/cgi/viewcontent. } \\
& \text { cgi?referer=https://www.google.co.uk/\&httpsredi } \\
& \underline{\mathrm{r}=1 \& \text { article }=2947 \& \text { context=faculty scholarship }} \\
& 12 \text { ibid, } 677
\end{aligned}
$$


ICCPR, Convention Against Genocide and Convention Against Torture. ${ }^{13}$ As a result, it is not a matter of domestic concern rather a concern of the international community. Therefore, it is to be kept in mind that derogation measures should not be inconsistent with international law. ${ }^{14} \mathrm{We}$ know that some international treaties dealing with the situation of the state of emergency and those treaties have made provisions of derogable and non-derogable rights. Although the list varies in different treaties, there are some common rights that exist across all the treaties. These are the right to life, the prohibition of slavery, prohibition of torture or to cruel, inhuman, or degrading treatment or punishment and prohibition of retroactive penal measures. ${ }^{15}$ Article 4 of the International Covenant on Civil and Political Rights (ICCPR) deals with the state of emergency and Article $4(2)^{16}$ provides a list of non-derogable rights. The rights under Article 4(2) of the ICCPR cannot be derogated during a state of emergency. During a state of emergency, if any state violates any right incorporated in Article 4(2) of the ICCPR then the state has to explain the cause of action. In addition, Article 22(2) of the ICCPR states that:

"No restrictions may be placed on the exercise of this right other than those which are prescribed by law and which are necessary in a democratic

13 ibid

${ }^{14}$ Human Rights Committee, General Comment 29 (2001) (The Human Rights Committee is the body of independent experts that monitors implementation of the International Covenant on Civil and Political Rights by its State parties), 2001, Para 16

15 European Convention on Human Rights 1950, Article 15.2; American Convention on Human Rights 1978, Article 27.2

${ }^{16}$ International Covenant on Civil and Political Rights 1966, Article 4(2) provides that "No derogation from articles 6, 7, 8 (paragraphs I and 2), 11, 15, 16 and 18 may be made under this provision". society in the interests of national security or public safety, public order (ordre public), the protection of public health or morals or the protection of the rights and freedoms of others. This article shall not prevent the imposition of lawful restrictions on members of the armed forces and of the police in their exercise of this right."

Article 22(2) clearly explained that when a state can derogate rights and when a state cannot. In addition, derogations can never sanction acts of genocide, torture or crimes against humanity. ${ }^{17}$ This was subsequently reaffirmed in the case of Chahal $v$. the United Kingdom. In this case, the European Court of Human Rights absolutely prohibits torture or inhuman or degrading treatment or punishment in public emergency or any other circumstances. ${ }^{18}$ This rule was again used in the case of Saadi v. Italy, where the European Court stated that Article 3 , which prohibits in absolute terms torture and inhuman or degrading treatment or punishment, enshrines one

17 Human Rights Committee, General Comment 29 (2001), Article 13(c) (The Human Rights Committee is the body of independent experts that monitors implementation of the International Covenant on Civil and Political Rights by its State parties); Article 22 of the Convention against Torture states that "No exceptional circumstances whatsoever, whether a state of war or a threat of war, internal political instability or any other public emergency, may be invoked as a justification of torture"

${ }^{18}$ Chahal v. the United Kingdom, judgment of 15 November 1996, Application no. 22414/93, Reports 1996-V, (1996), Para 79. 
of the fundamental values of democratic societies. ${ }^{19}$

Non-derogable rights cannot be suspended, but the state can put some restrictions on a few non-derogable rights. For example, under Article 4(2) of the ICCPR, freedom of religion (article 18 of the ICCPR) is a non-derogable right but it may be subject to limitations in accordance with Article 18(3). The right to life (Article 6 of the ICCPR) is another example of nonderogable right. However, taking life could be justified on the basis of circumstances, where it is in the nature of absolute necessity, reasonable, and proportionate. The above discussion of Articles 4 and 22 of the ICCPR clearly shows that derogation is possible in the state of emergency. However, Article 4(2) also provides that which rights cannot be derogated at any circumstances.

\section{Derogation Under The Constitution Of Bangladesh:}

We all know the fact that fundamental rights provide the citizens self-esteem of life, freedom and justice. But only having these sets of rights in the Constitution are not enough to protect the citizens, a strong judiciary is needed to protect those rights. The Constitution of Bangladesh has confirmed some fundamental rights for the citizens of Bangladesh which was actually inspired by the Universal Declaration of Human Rights, 1948. Aiming to ensure equality was one of the main grounds behind incorporating some fundamental rights. These rights have been incorporated in Part

\footnotetext{
${ }^{19}$ Saadi v. Italy, judgment of 28 February 2008, Application no. 37201/06, 2008, Para 127.

20 In the Constitution of Bangladesh, there are 18 fundamental rights available in Articles 27-44 for the citizens of Bangladesh.

21 M. Ehteshamul Bari, The Unjust Exercise of Emergency Powers in Bangladesh and Their Consequent Impact on the Fundamental Rights: A
}

III of the Bangladesh Constitution. ${ }^{20}$ All of these 18 rights are civil and political rights. However, all of them are not absolute in nature. Here we can notice three different types of rights; such as: absolute rights, qualified rights and rights which enforceability has been practically left to the legislature. There are 8 absolute rights mentioned in Articles 27-30, Articles 33- 35 and Article 44. In addition to these, six qualified rights are available, and they have been incorporated under Articles 36-40 and 43. Lastly, there are 4 rights whose enforceability left to the legislature; such as Articles 31, 32, 40 and 42.

As mentioned earlier that state may suspend some rights during emergency which is widely recognised around the world as well as in Bangladesh. Although it is a matter of question that which rights could be suspended during emergency. In case of Bangladesh, it is very vital to clarify this question as we know that since the inception of Bangladesh, emergencies have been proclaimed on 5 times. ${ }^{21}$ Part IXA of the Constitution deals with the emergency provisions. $^{22}$ Under Article 141B, the issuance of the proclamation automatically suspends the operation of the fundamental rights guaranteed under Articles 36-40 and 42. The difference between Articles 141B and $141 \mathrm{C}$ is that while Article 141B suspends the specified fundamental rights, a proclamation under Article 141C does not suspend any fundamental right, but merely suspends enforcement of such fundamental rights. In Iqbal Hasan Mahmood vs.

Critical Appraisal, Mykolas Romeris University, Vol 21, Issue No: 2(2014) P 584

${ }^{22}$ Part IX of the Constitution deals about proclamation of emergency(Article 141A), Suspension of provisions of certain articles during emergencies(Article 141B) and Suspension of enforcement of fundamental right during emergencies(Article 141C). 
Bangladesh $^{23}$, the High Court Division accepted the view of an Amicus Curiae that proclamation under Article 141C does not have the effect of suspending the fundamental rights other than those mentioned in Articles 36 to 40 and 42 and the same proclamation does not empower the government to act contrary to those rights. ${ }^{24}$ This reference clearly shows that the President is not permitted to derogate all of the fundamental rights enumerated in Part III of the Bangladesh Constitution. But, surprisingly, in practice, we have seen that all of the 18 fundamental rights had been suspended during the emergency. For example, in 2007, President Iajuddin Ahmed declared a state of emergency in the country and suspended 18 fundamental rights. ${ }^{25}$ This was for the first time when Bangladesh suspended all of these 18 rights while in the past, only 12 rights were suspended during all the previous 4 emergency regimes. ${ }^{26}$ This practice was quite unprecedented in the history of Bangladesh because we know that the state cannot suspend some absolute rights mentioned in the ICCPR. Although Bangladesh has become a state party of the ICCPR on $6^{\text {th }}$ September $2000^{27}$, but since then the Constitution of Bangladesh has not been amended and no government has incorporated those seven non-derogable rights contained in the ICCPR into the Constitution of Bangladesh. As we see that there is no clear Constitutional provision of which rights cannot be suspended, the state can misuse the emergency provision.

${ }^{23} 60$ DLR(AD) 880 (2008)

24 MAHMUDUL ISLAM, CONSTITUTION OF BANGLADESH, Mullick Brothers, $429\left(3^{\text {rd }}\right.$ Ed 2012)

25. Carol Christine Fair, On the Issues: Bangladesh. Washington DC: United States of Institute of Peace, 27 April 2007, p. 1; see: https://www.usip.org/publications/2007/04/issues -bangladesh
Therefore, those 7 non-derogable rights should be incorporated in part IXA of the Constitution.

\section{Derogation Under The Case Of Ataur Rahman Vs Muhibur Rahman:}

Ataur Rahman vs Muhibur Rahman[2009] 14 BLC (AD) is an important case which deserves to be revisited and must be contextually understood as regards the suspension of any fundamental rights conferred by part III of the Constitution during the period of an emergency. The case is also significant to understand the interpretation of the term "equality before law" as enshrined in Article 27 of the Constitution. The Appellate Division observed that "all persons are not equal in all respects and that persons similarly situated should be treated alike". ${ }^{28}$ Although "equality before law" is a particular law but it cannot be used uniformly to all persons with different groups or categories according to their distinctions. Therefore, classification is reasonable to provide them special treatments to ensure justice. Positive discrimination could be justified sometimes where equality does not work all the time, but equity does. It is a process of giving preferential treatment, especially in employment for the exceptional circumstance. In the case of Ataur Rahman, the preferential treatment was necessary to justify the outcome.

In this case, one group of teachers asked for an exemption from departmental

\footnotetext{
${ }^{26}$ M. Ehteshamul Bari, supra note 21, p 591

${ }^{27}$ International Covenant on Civil and Political Rights, 1966; see: https://treaties.un.org/Pages/ViewDetails.aspx?src $=$ IND\&mtdsg no=IV-4\&chapter=4\&clang= en

28 Ataur Rahman v. Muhibur Rahman 14 BLC (AD) 62, 69, para 16 (2009)
} 
examination on the apprehension that they would not be successful in the departmental examination and foundation training. This group of teachers was appointed on 20-121998 to the Bangladesh Civil Service (General Education) Cadre. Another group of teachers from various government colleges could not take the departmental examination as well as foundation training as required of them by the Recruitment Rules, 1981 within the period of their probation. This group of teachers was appointed prior to 12-01-1992 to the Bangladesh Civil Service (General Education) Cadre. However, it was not their own fault but for the reason that the Government could not make any arrangement for holding such examination and training. These two several incidents have caused the same fate for two groups of teachers and they were being unduly prejudiced discriminated in the matter of their confirmation in service and promotion to the senior scale. To remove this injustice and inequality, the President promulgated the impugned Statutory Regulatory Order (SRO) 11-10-2006 to provide an exemption to those teachers who couldn't take departmental examination and foundation training. It is to be kept in mind that, it was the time of state emergency while the President promulgated the SRO 2006 dated 11-10-2006. The High Court Division said that the aforesaid SRO 2006 dated 11-10-2006 was illegal and unconstitutional as it violates the rights guaranteed under Articles 27(Equality before law), 29(Equal Opportunity in public employment) and 31(Right to protection of Law) of the Constitution being arbitrary and discriminatory.

\footnotetext{
${ }^{29}$ Supra note 14, Human Rights Committee, General Comment 29 (2001) (The Human Rights Committee is the body of independent experts
}

The Appellate Division addressed amongst others two important issues in this case, (i) Whether or not the SRO 2006 dated 11-10-2006 was illegal and unconstitutional violating the provisions of Articles 27, 29 and 31 of the Constitution being arbitrary and discriminatory? (ii) Whether or not the state of emergency in the country should be taken to have barred enforceability of the fundamental rights envisaged in the aforesaid Articles of the Constitution? And (iii) Whether or not the President has the power to amend or vary the Bangladesh Civil Service Recruitment Rules, 1981 made by him in the exercise of Article 133 of the Constitution?

The apex court observed that,

"The President in terms of Article $141 C(1)$ is empowered to suspend the enforcement of any of the fundamental rights conferred by Part III during the period when a proclamation of emergency is in operation. It is for the President to decide the enforcement of which of the fundamental rights should be suspended during the operation of the proclamation of emergency and this power is not liable to be circumscribed or limited by any other provisions in the Constitution including Article 26". ${ }^{29}$

This reading of the provision begs a question whether or not it makes Article 141B of the Constitution superfluous. It should not be difficult to understand the language of Articles 141B and 141C. In case of Article 141B, any action out of Articles 36 to 40 and 42 during the continuance of emergency creates no cause of action as those fundamental rights remained suspended 
during that period and the aggrieved person cannot challenge an action in violation of those fundamental rights even after lifting of emergency. On the other hand, in case of Article 141C, an action in violation of fundamental rights ensured under Articles 27 to 35 and 41 creates a cause of action because these fundamental rights cannot be suspended during emergency. ${ }^{30}$ Therefore, the aggrieved person can challenge the action after lifting of emergency. ${ }^{31}$

This provision is clearer in the Article 359(1) of the Indian Constitution, 1950. It says,

"Where a Proclamation of Emergency is in operation, the President may by order declare that the right to move any court for the enforcement of such of [the rights conferred by Part III (except Articles 20 and 21)] as may be mentioned in the order and all proceedings pending in any court for the enforcement of the rights so mentioned shall remain suspended for

${ }^{30}$ Supra note 12, Joan Hartman, 'Derogations from Human Rights Treaties in Public Emergencies 22 Harvard International Law Journal, 6 (1981), 430 31 ibid

32 Jus Cogens is a Latin phrase and the general meaning of it is 'compelling law'. Porfessor Ian Brownlie explain the meaning of 'Jus Cogens' in his famous book titles "Principles of Public International Law'. 'Jus cogens' refers to certain fundamental, overriding principles of international law, from which no derogation is ever permitted. These norms are well accepted by the international community to maintain an international order. This doctrine was developed under the influence of natural law concepts, which maintain that states cannot be absolutely free in establishing their contractual relationship. States were bound to respect certain fundamental principles which were deeply connected with the international community[ see: Gennady M. Danilenko, International Jus Cogens: Issues of Law-Making, 2 EUR. J. INT'L L. 42, 44 (1991), available at http://www.ejil.org/journal/Vol2/No1/art3.html.]. These rules cannot be altered during war as well as in the peace time. This is why the position of the rules of jus cogens is hierarchically superior the period during which the Proclamation is in force or for such shorter period as may be specified in the order."

It means the President of India can suspend the right to move any court for the enforcement of such rights conferred by Part III [except Article 20(Protection in respect of conviction for offenses) and Article 21(Protection of life and personal liberty)]. From this provision of Indian Constitution, it is clear that right to life (jus cogens) ${ }^{32}$ is not derogable. In the case of ADM Jabalpur $\boldsymbol{v}$. Shivkant Shukla (1976) AIR SC 1207, what the court except for Khanna ${ }^{33}$, J. failed to realise is that the right to life is not a 'gift of the Constitution'. ${ }^{34}$ Article 4 of the ICCPR recognises the right to life and personal liberty to be a non-derogable right even during times of emergency. ${ }^{35}$ Arbitrary killing in the state emergency creates a cause of action and the state has to explain the

compared to other ordinary rules of international law.

33 Justice Khanna said in his dissenting judgment that "Article 21 cannot be considered to be the sole repository of the right to life and personal liberty. The right to life and personal liberty is the most deceive right of human beings in civilised societies governed by the rule of law. Sanctity of life and liberty was not something new when the Constitution was drafted. It represented a facet of higher values which mankind began to cherish in its, evolution from a state of tooth and claw to a civilized existence. The principle that no one shall be deprived of his life and liberty without the authority of law was not the gift of the Constitution. It was a necessary corollary of the concept relating to the sanctity of life and liberty; it existed and was in force before the coming into force of the Constitution."

${ }^{34}$ Harshit Khare, Position of Fundamental Rights during Emergency, (15 March 2011) <http://www.legalservicesindia.com/article/article /position-of-fundamental-rights-duringemergency-589-1.html > (accessed 15 September 2016)

35 ibid 
reason behind any arbitrary killing. ${ }^{36}$ Although Article 4 of the ICCPR said that what a state party could do during state emergency and a list of non-derogable rights but also the Article 13(A) of the General Committee 29 of the Human Rights Committee says that,

"All persons deprived of their liberty shall be treated with humanity and with respect for the inherent dignity of the human person".

From the above discussion, it is clear that there are two kinds of fundamental rights; derogable and non-derogable. However, in the Constitution of Bangladesh, there is no such kind of classifications, but we have found out some fundamental rights create a cause of action and some rights cannot create any cause of action. But in the case of Ataur Rahman vs Muhibur Rahman, the Apex court of Bangladesh interpreted those rights without any classifications. The court also said that it is for the President to decide the enforcement of which of the fundamental rights should be suspended during emergency. This statement is actually creating blanket immunity of the government to abuse the Constitutional rights of the people of Bangladesh. Hence, this holding is flawed. Fundamental rights are the protected rights of our Constitution. Some fundamental rights are even universally recognised rights which are contained in the United Nations Universal Declaration of Human Rights, the U.N. International Covenant on Civil and Political Rights, or the U.N. International

36 Although right to life is not permitted during emergency but, use of force against life can be permitted in the case of absolute necessity: a) in defence of any person from unlawful violence; $b$ ) in order to affect a lawful arrest or to prevent the escape of a person lawfully detained; c) in action lawfully taken for the purpose of quelling a riot or
Covenant on Economic, Social and Cultural Rights. Such as the right to life, the prohibition of torture, slavery etc. These rights cannot be derogated during a state of emergency. However, the decision of the court in Ataur Rahman v. Muhibur Rahman is erroneous decision, where the Apex court of Bangladesh tried to justify that the President can derogate any fundamental right during an emergency. Such a proposition is contradicting core parts of our Constitution as well as several international instruments. It seems to us that our Constitution has given the power to the President to suspend certain fundamental rights under Article 141C of the Constitution but, cannot suspend Articles 27 to 35 and 41 of the Constitution.

\section{CONCLUSIONS AND SUGGESTIONS}

To get back the peace in the country, sometime, it is very much essential to derogate certain rights during emergency. However, derogation shall not be a weapon that can be used as a veil in certain violating human rights. Undoubtedly, these basic human rights are so imperious for stabilising humanity. Suspending them would actually destroy the human essence and also will be against the concept of 'rule of law'. Rule of law considers the power laws, but not the power of men. The men who possess power should remember that a man can go higher and higher but, the laws are above the man. ${ }^{37}$ Justice Jagdish Singh Khehar rightly cited the meaning of rule of law which was explained by Jeffrey Jowell in his seminal article "The Rule of Law Today":

insurrection. See: McCann and others v United Kingdom 21 ECHR 97 GC (1995), Osman v United Kingdom EHRR 101 (1998) where killing was justified.

${ }^{37}$ U/A 143(1) Of Constitution vs Of India on 27

September 2012, p 87, para 36 
"Rule of law principle primarily applies to the power of implementation. It mainly represents a state of procedural fairness. When the rule of law is ignored by an official it may on occasion be enforced by courts." 38

Procedural fairness is one of the core foundations in implementing human rights. To ensure rule of law, state should avoid using arbitrary power. ${ }^{39}$ In another perspective, these rights are so important to control the behavior of a human being. Therefore, ensuring these rights would essentially approve the sustenance of human life. The progression of the global protection of human rights has been sculpted by several national and international instruments. It is necessary to remember that the purpose of declaring an emergency is to protect the value of the society which is subjected to a provisional threat. An emergency should not be declared for the purpose of making sarcasm which will scrape out the idea of 'rule of law'. No matter how serious an emergency is should always follow the minimum standard; otherwise, it will destroy the bond between legality and democracy and also will terminate all impression of a decent and civilised life.

\section{REFERENCES}

\section{Book}

Emilie M. Hafner-Burton, Laurence R. Helfer, and Christopher J. Fariss, Emergency and Escape: Explaining Derogations from Human Rights Treaties, (International Organization of Duke University: 2011), 676

M. Ehteshamul Bari, The Unjust Exercise of Emergency Powers in Bangladesh and Their Consequent Impact on the Fundamental Rights: A Critical Appraisal, (Mykolas Romeris University: 2014)

Mahmudul Islam, Constitution of Bangladesh, (Mullick Brothers: 2012)

Carol Christine Fair, On the Issues: Bangladesh, (Washington DC: United States of Institute of Peace: 2007)

\section{Journal Articles}

Muhammad Nasrullah Virk, 'Doctrine of Necessity-Application in PakistanCases of Immense Importance- A
Critical Review' (2012) 2 (2) International Journal of Social Science and Education, 83

Joan Hartman, 'Derogations from Human Rights Treaties in Public Emergencies' (1981) 22 Harvard International Law Journal, 6

Gennady M. Danilenko, 'International Jus Cogens: Issues of Law-Making', (1991) 2 European Journal of International Law, 42

\section{International Convention}

International Covenant on Civil and Political Rights 1966

United Nations Universal Declaration of Human Rights (UDHR)

UN International Covenant on Civil and Political Rights (ICCPR)

UN International Covenant on Economic, Social and Cultural Rights (ICESCR). 


\section{Legislations}

European Convention on Human Rights 1950

Bangladesh Constitution

legislation of 1958 Martial Law

\section{Cases}

The State[Pakistan] vs. Dosso and Another [1958] PLD SC (PAK.) 533

Ataur Rahman v. Muhibur Rahman 14 BLC (AD) 62, 69, para 16 (2009)

\section{Internet Sources}

George Williams, The Case that Stopped a Coup? The Rule of Law in Fiji $\left(27^{\text {th }}\right.$ November 2003) $\quad \mathrm{s}<$ http://www.victoria.ac.nz/law/centres/ nzcpl/publications/occasional-papers/ publications/OP_Williams.pdf > (accessed 15 September 2016)

Harshit Khare, Position of Fundamental Rights during Emergency, (15 March 2011)

<http://www.legalservicesindia. com/article/article/position-offundamental-rights-duringemergency-589-1.html $>$ (accessed 15 September 2016) 